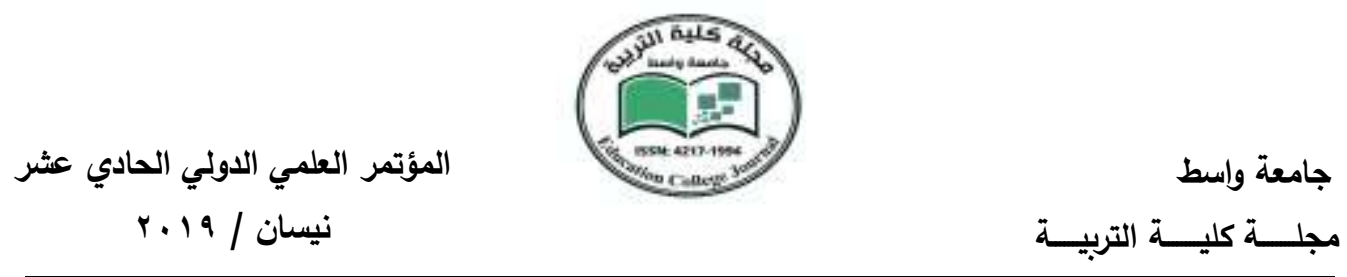

\title{
A Stylistic Study of Repetition and Ideology in Political Discourse: Donald Trump as a Case Study
}

\author{
Asst.prof. Azhar Hassan Sallomi \\ University of Karbala \\ College of Education for Humanities \\ hasan.adel.633@gmail.com
}

\author{
Asst. prof.Dr. Muayyad Omran Chiad \\ University of Karbala \\ College of Education for Humanities \\ muyyadomran2@yahoo.com
}

\begin{abstract}
The challenging debates including the political one witness the presence of many ways conveying related views but not totally similar .Repetition is one of these variants which play an essential role in communication as speakers embrace a particular strategy in their choice to accomplish certain tasks. This paper investigates the phenomenon of repetition, its individualities, categories, the motives behind the manifestation of its different types, and the ideological function in the political discourse of Donald Trump, the president of the United States. Both Kemertelidze and Manjavidze's (2013) model and van Dijk's (1988) ideological square are adopted to identify the sorts of repetition and ideology accessible in Trump speeches. Thus, repetition in the present study does not only refer to its role as a stylistic cohesive device, but also to its function as a rhetorical device that carries a definite ideology to the audience. The paper reveals that Trump tends to use repetition and specifically anaphora and epiphora as he realizes well how such forms enhance the rhythmic blend of speech owing to the development of intonation and sound uniqueness at initial or final position of a sentence. Additionally, Trump intends consciously to repeat a word, a phrase, and even a sentence to accomplish goals like illumination, prominence, persuasion, warning, making a point memorable, and creating cohesion .Using such a vital instrument, he succeeds to have his own effect or authority upon listeners, manipulate them, and accordingly form an attitude.
\end{abstract}

Key words: Repetition, Political discourse, Anaphora, Epiphora, Ideology 

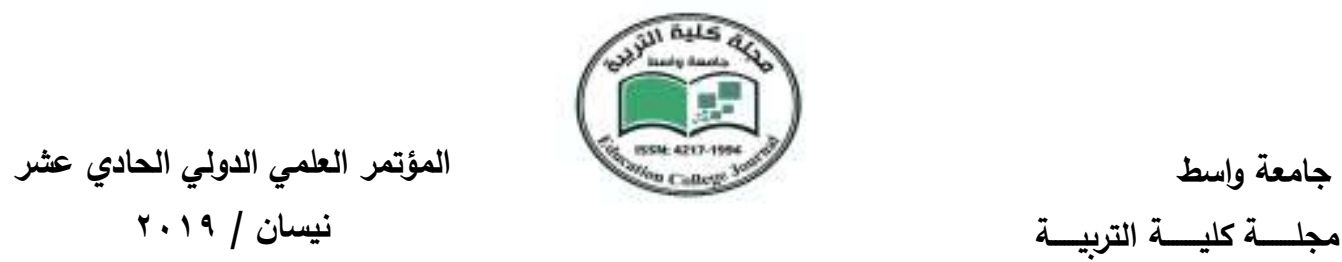

\section{Introduction}

In political speeches which are known for their argumentative debate, speakers use a definite style represented by numerous altered devices at all levels of expression that help in constructing an operative discourse. The stylistic devices perform a supreme part in the analysis of any text as they employ figures of speech that build a glowing image of the text. Among other figures of speech, repetition is one of the widely used syntactic stylistic devices.

Repetition, being one of the stylistic strategies that can occur at three altitudes of language, has its own vital role in implementing more than one task in any discourse and political one is no exception. The noun " repetition" itself conveys two key senses : an affair that repeats the act of doing or performing again and the repeated use of the same word or word pattern as a rhetorical device (Sandell, 1977: 75). Repetition can be used both constructively and destructively. The fruitful usage embraces utilities such as, setting emphasis on a point, approving a fact or an idea, cohesion, persuasion shift, exhibiting objectivity, and unfolding a concept. The reproachful use of repetition, on the other hand, can flop the entire piece of writing as it implicates disparaging effects like disintegration, rejection, termination, and unremitting present .Cuddon (1998: 742) ,confirms the constructive aspect and argues that repetition refers not only for repeating words but also sounds and ideas for the purpose of provoking rhythm, and fashioning emphasis. Power (1998: 25) adds that in persuasive discourse, for instance, a speaker may use such device in order to heighten his speech and interactively achieve the task of persuasion. The following lines from Samuel Beckett's novel "Malone Dies" illustrate how repetition is used, for instance, to fulfill the purpose of emphasis:

" Lemuel is in charge, he raises his hatchet on which the blood will never dry, but not

hit anyone, he will not hit anyone, he will not hit anyone anymore..." 

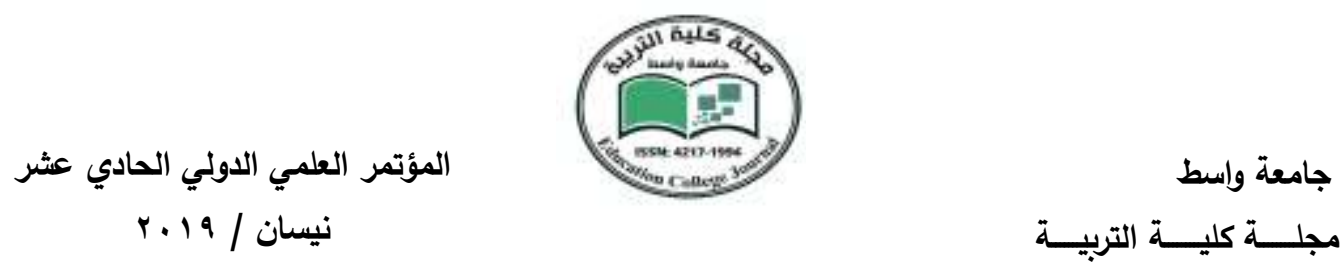

The aura that is fashioned by the use of repetition cannot be fulfilled via any other device .Using repetition leads to make a simple sentence sounds like a dramatic one. It enriches the beauty of a sentence and adds tensions to the point of core connotation. Word associations are sometimes used to replicate the notions and passions in a subsidiary manner; readers may enjoy reading a piece that comprises repetition as they have to interpret such connotations and appreciate the crucial meanings. One can conclude then that repetition can fulfill a variety of tasks in any discourse including the political one . The concealed ideologies the political discourse convey and its momentous power have fortified a vast number of researchers to probe in this extent. Investigating the stylistic devices used in such discourse is one of the tools adopted to inspect the hidden ideology in political discourse. This paper pinpoints the categories of repetition and shows the motives behind their manifestation in political discourse .Trump's speeches are selected as a sample for the English political discourse. In this study, the researchers seek to answer the following questions:

1. What are the brands of repetition used by Donald Trump?

2. What are the motives behind the use of repetition?

3. How does Trump encode repetition in constructing reality and legitimatizing his ideology?

4. Does he employ the ideological strategy of us vs them to construct his political discourse?

5. What conclusions and recommendations that can be drawn from the study?

In relation to the questions above, the study aims to achieve the following objectives:

1. Identifying the types of repetition occurred in the political discourse.

2. Finding out the purposes behind the use of repetition.

3. Poiting out the different ways used by Trump in constructing a specific reality for his audience.

4. Examining the ways in which he employs the polarization strategy of us vs them.

5. Giving some conclusions and recommendations based on the findings. 


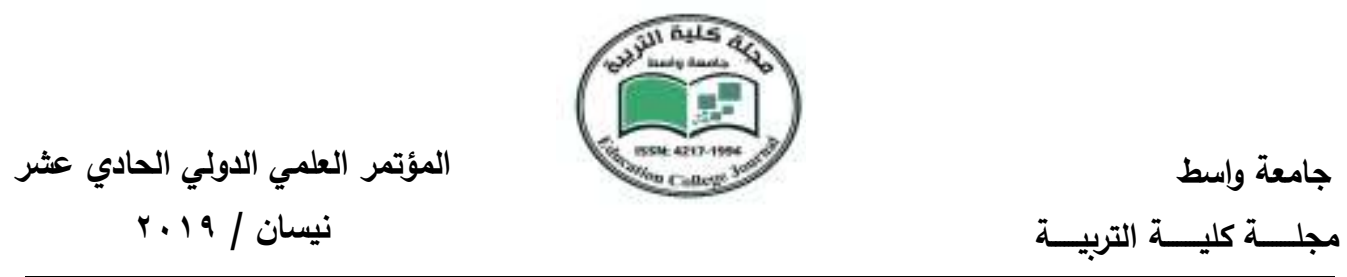

2. Methodology of the study

\subsection{Materials}

The materials comprise online five political discourses by Trump through different occasions and through the years 2016 and 2017 , are randomly selected as a sample for English political discourse. The transcripts were downloaded on September $23^{\text {rd }} 2018$ from reputable internet websites given at the end of the study in the list of references. These speeches are: (1) Trump's victory Speech in November 9,2016 (2) Trump Inauguration in January, 20, 2017 (3) The Foreign Policy Remarks in April 27, 2016, (4) 'Illegal Immigration' in August 31, 2016, and (5 ) Israeli- Palestinian Peace and The U.S - Israeli alliance in May, 23,2017 .

\subsection{Procedure}

The data are analyzed quantitatively and qualitatively to identify the categories of repetition as given in Kemertelidze and Manjavidze's model (2013), and the ideology according to van Dijk (1988). The researchers selected such models because they are more appropriate and applicable in the analysis of political discourse. The data are scanned quantitatively through applying the statistic program SPSS. In addition, the motives behind the use of repetition are explained in the speeches with reference to their context of occurrence. The relation between ideology and repetition is decontextualized to reveal the different ways in which the politician portray constructs a frame for his underlying ideology. 

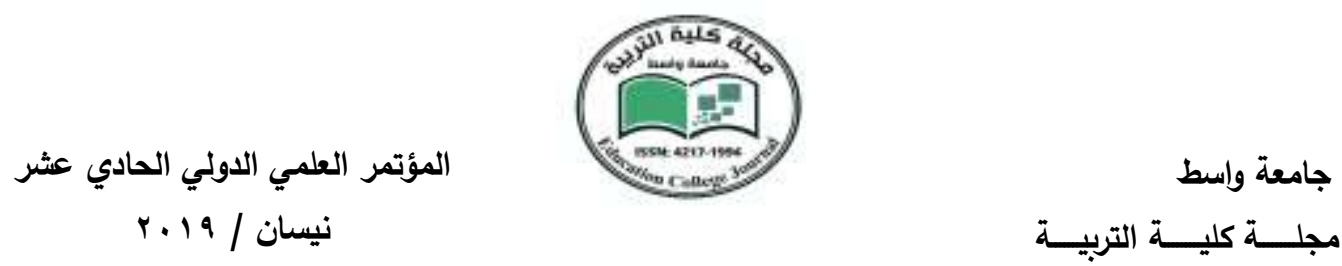

3- Repetition

Repetition displays the reasonable emphasis that is essential to captivate a reader's or listener's attention on the key-word or a key-phrase of the text or speech. It indicates repeating sounds, words, expressions, clauses and even sentences in a definite succession to deliver emphasis. According to the place where repeated words occur in, Kemertelidze and Manjavidze (2013: 4) classify repetition into the following categories that are explained separately:

\subsection{Anaphora}

It is the repetition of a word or a phrase at the beginning of two or more uninterrupted sentences. Consider the following examples:

1- We will face challenges. We will confront hardships. We are going to fix our inner cities. We are going to rebuild our high ways. (Trump's $1^{\text {st }}$ speech) 2- From this day forward, a new vision will govern our land .From this day forward, it is going to be only America.( Trump's $5^{\text {th }}$ speech)

3- It is time to shake the rust off America's foreign policy .It is time to invite new voices and new visions into the fold. ( Trump's $4^{\text {th }}$ speech )

\subsection{Epiphora}

It is sometimes called epiphoric repetition in which one and the same word or phrase is placed at the end of successive sentences. For instance:

1. We will deal fairly with everyone, with every one .(Trump's $1^{\text {st }}$ speech)

2. They look up at the same night sky. They fill their heart with the same dreams. (Trump $3^{\text {rd }}$ speech)

3. We must treat them really, really well. (Trump's $5^{\text {th }}$ speech ). 

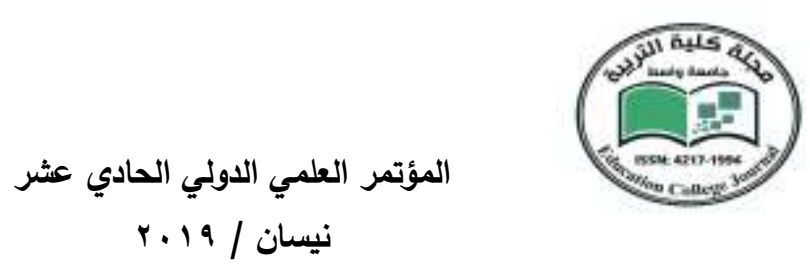

\subsection{Anadiplosis}

It is the repetition of the same word at the end of one and at the beginning of the following clauses, sentences as in the examples below :

1. America will start winning. Winning like never before. (Trump's $5^{\text {th }}$ speech )

2. I mean she. She fought very hard .( Trump's $1^{\text {st }}$ speech )

3. We have a massive trade deficit with China.A deficit that we have to find a way quickly.( Trump's $3^{\text {rd }}$ speech )

\subsection{Framing}

This type is systematized in the form of a frame. The initial parts of a syntactical unit usually, in most cases of a paragraph, are repeated at the end of it. This type of repetition succeeds to make the entire utterance more compressed and more comprehensive. Framing is most operative in singling out paragraphs. Though one can meet a countless deal of it in emotive prose, it is more often found in poetry. Via framing any part of text - a sentence, a paragraph, and a page can be comprised. Sometimes it starts from the title and covers the whole text and this occurs when the first word and the last one in the text are alike . Concerning the political discourse, this sort is common at sentence level rather than paragraph or page as in the following example:

1. We expect to have great relationships, no dream is too big, no challenge is too great. (Trump's $4^{\text {th }}$ speech)

2. Their victories have not been your victories. (Trump's $1^{\text {st }}$ speech)

3. Clinton blames it all on video, an excuse that was a total lie, proven to be absolutely total lie. (Trump's $3^{\text {rd }}$ speech) 

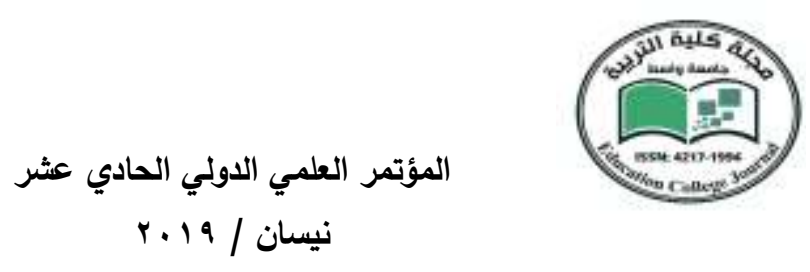

\subsection{Rooted}

The same root is repeated in this sort rather than the same words. For instance:

1. President Obama has weakened our military by weakening our economy. (Trump's $4^{\text {th }}$ speech)

2. We have a great economic plan. We will double our growth and have the strongest economy any where in the world. (Trump's $1^{\text {st }}$ speech)

3. We must think big and dream even bigger. (Trump's $2^{\text {nd }}$ speech )

\subsection{Synonymous}

The word or phrase is repeated with its synonym in this category. For example:

1. The bible tells us how good and worthy it is when God's people live in unity. (Trump's $2^{\text {nd }}$ speech )

2. And also my late brother, Fred . Great guy, fantastic guy.( Trump's $1^{\text {st }}$ speech )

3. The bible tells us how good and pleasant it is when God's people live together in unity.(Trump's $5^{\text {th }}$ speech )

\subsection{Scattered}

Throughout the whole text, a word, a phrase, a sentence is repeated several times. Though structurally this type does not tie with any current type of repetition, its goal is the same. It is called scattered repetition as it is seen here and there in the text without any definite order. The examples below mention some scattered words or phrases in both Trump's speechs:

1. It is time (Trump's $4^{\text {th }}$ speech)

2. America (Trump's $2^{\text {nd }}$ speech)

3. President Obama, Radical Islam (Trump's $3^{\text {rd }}$ speech) 

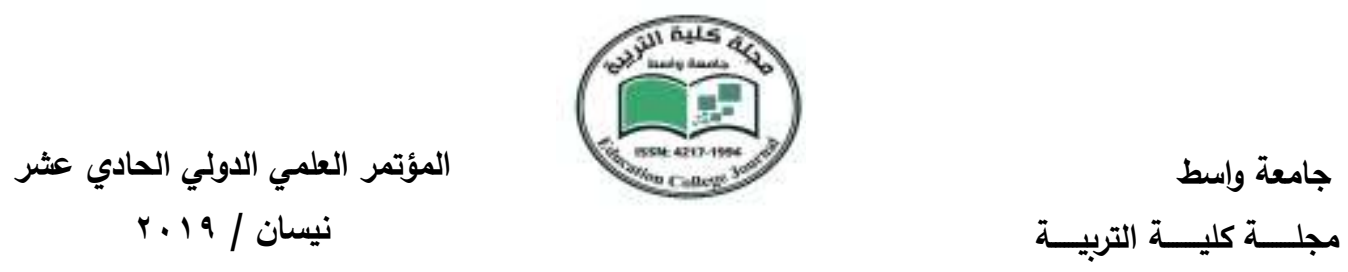

\section{8 Thematic}

In this brand, the theme of the text is repeated without any precise prototypes of repetition. Below some of themes mentioned in the data under study:

1- Thanking people who helped Trump in his victory. (Trump's $1^{\text {st }}$ speech)

2- Trump's promise to American people. (Trump's $4^{\text {th }}$ speech)

3- Criticizing Obama's policy. (Trump's 5th speech)

\section{9 Chain Repetition}

This type of repetition efficiently cultivates logical reasoning. It is a thread of several successive anadiploses. The selected sample lacks this type of repetition and this explains why no examples are offered to illuminate it.

\section{4- Purposes of Repetition}

In his book " Categories and Functions of Repetition in Turkish Oral Narratives", Yemenici( 2002: 20-21) discusses the motives behind the use of repetition .To him , repetition is the most distinctive stylistic device of the fluent style and can fulfil tasks like persuasion, emphasis, attracting the attention of listeners and making speech more memorable. By repeating a phrase, clause, or sentence, one can highlight a vital thought. As an example from poetry, Emily Dickinson reveals in her poem "Nobody" how she is able to emphasize her attitude and create an association with the person she is talking about through the repetition of the word 'nobody'.

I'm nobody! Who are you?

Are you nobody too?

Then there's a pair of us-don't tell!

They'd banish us you know.

The same motive of emphasis achieved via repetition may occur in prose .In one of his speeches, Trump, for instance, repeats the phrase (we will bring back) at the beginning of successive sentences like (we will bring back our jobs), (we will bring back our borders ), (we will bring back our wealth), and (we will bring back our dreams ). Through such 

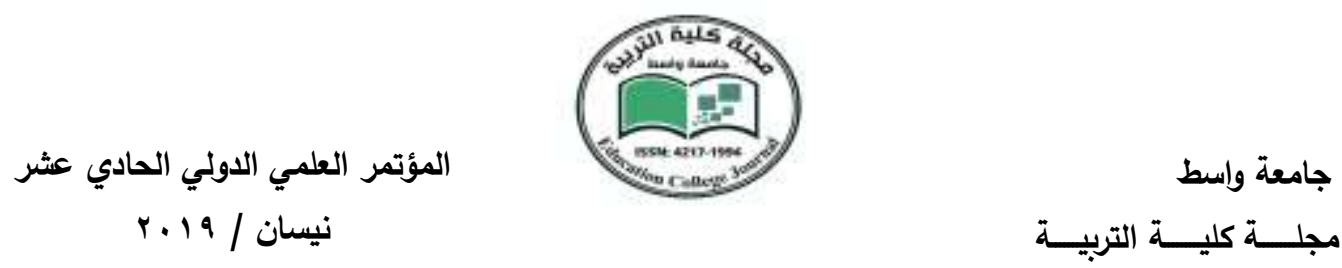

anaphora repetition, Trump confirms his promises to Americans and how he will make all their dreams come true. The musical harmony created from the anaphora repetition of the same phrase supports a lot in appealing to the audience, attracting their attention, and inviting them to believe in Trump's promises.

\section{5- Ideology}

Ideology is a crucial concept in the analysis of political discourse .It can be viewed as a system of ideas, views or a way of looking into the issues of life. Many scholars have defined the term in many ways.

As for the Marxist, ideology is related to ascendancy and power of the ruling aristocracy. This power and dominance which the aristocracies enjoy allow them to decide what is appropriate and suitable in the society (van Dijk, 1998, : 97). Thompson(1990:vii) defines ideology as "social forms and processes within which and by means of which, symbolic forms circulate in the social world". Fairclough ( 1992:87) gives a definition of ideology as a construction of reality whether physical world , or social relations or social identities which might be constructed into different dimensions of the form/meaning of discursive practices. Hodge and Kress (1993:6) define ideology as "a systematically organized presentation of reality". Van Dijk ( 1995:139) points out that the dominant groups have ideologies not only to legislate their power but to organize the social representations which they need for resistance and change. Ideologies are not the property of the dominant powers only, but other minority groups like journalists, institutions , etc. have ideologies. Hall (1996:26) contends that ideology represents "the mental frameworks, the languages, concepts, categories, imagery of thoughts and systems of representation" that persons use to stabilize power and dominance. Van Dijk (1998, : 9) agrees with Hall (1996) that ideology is a mental framework of beliefs that has the cognitive and social characteristic to regularize social practices. Van Dijk (1998:5) gives three components that are related to ideology:

1. Cognitively which connects ideology to thoughts in human beings' minds.

2. Societly which connects ideology to a group membership and value judgment. 

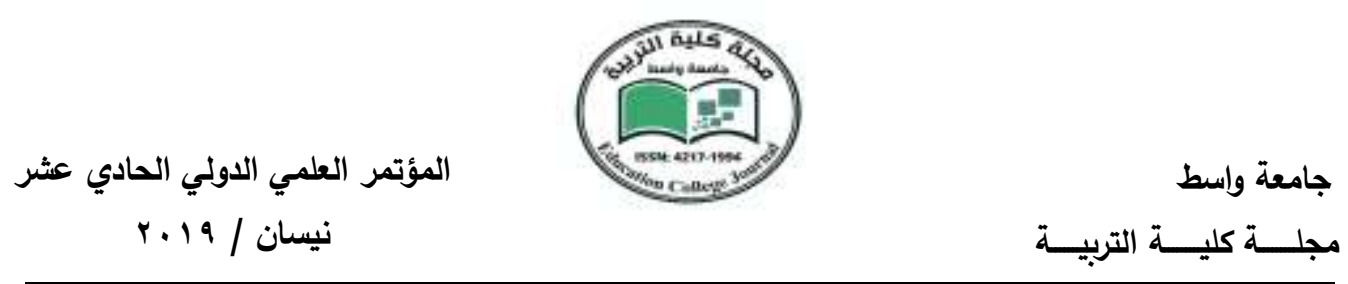

3. Linguistically which sees ideology not as innate knowledge, but it needs to be learnt, acquired, or changed through written or spoken discourse.

According to van $\operatorname{Dijk}(2001 b: 14)$, the social structure of ideology refers to a number of dimensions :

1. Memebership devices ( gender, ethnicity, appearance, origin, etc.): who are we?

2. Actions: what do we do?

3. Aims: why do we do this ?

4. Norms: what is good or bad?

5. Position: what is our position in society?

6. Rescourses: what is ours? What do we want to have/keep at all costs?

Besides being social related to group interests, conflict and struggle, ideologies may be deployed to validate or contest a given division of power and dominance (van Dijk,1998:5).The negative notion of ideology has additionally becomes the relevant element in the common sense, social sciences , and political uses, particularly as a system of false, misguided, a deceptive beliefs a contrary to the truth of scientific knowledge (van Dijk,2006:7).

Van Dijk (1998a, 1998b) posited The ideological square model . This model has a binary system of "us" associated with good and "them" associated with the value bad. This model enables the reader to categorize positive and negative representations of the two world politicians under study. The model is summarized as the following.

1. Emphasize our good properties / actions.

2. Emphasize their bad properties/ actions.

3. Mitigate our bad properties/actions.

4. Migtigate their good properties/actions. 

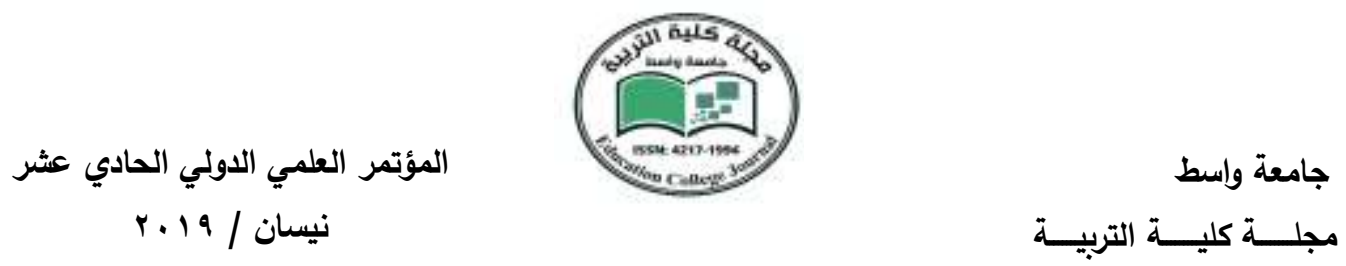

\section{6- Data collection and Analysis}

\subsection{Qualitative and Quantative Analysis of Repetition}

Types of repetition are investigated quantativly as well as qualitatively in Trump's speeches. Each speech is examined separately and from applying the statistic program SPSS . Table (1) below reflects the brands then the five speeches are compared with reference to the results obtained of repetition occurred in this discourse along with their regularity :

Table (1): Types of Repetition in Trump's speeches

\begin{tabular}{|c|c|c|c|c|c|c|c|c|c|c|}
\hline \multirow[b]{2}{*}{ speech } & \multirow{2}{*}{$\begin{array}{l}\text { Coun } \\
\mathrm{t} \& \%\end{array}$} & \multicolumn{8}{|c|}{ Type of repetition } & \multirow{2}{*}{$\begin{array}{l}\text { Tot } \\
\text { al }\end{array}$} \\
\hline & & $\begin{array}{l}\text { Anaph } \\
\text { ora }\end{array}$ & $\begin{array}{l}\text { Epipho } \\
\text { ra }\end{array}$ & $\begin{array}{l}\text { Anadipl } \\
\text { osis }\end{array}$ & $\begin{array}{l}\text { Roote } \\
\text { d }\end{array}$ & $\begin{array}{l}\text { Synony } \\
\mathrm{m}\end{array}$ & $\begin{array}{l}\text { Frami } \\
\text { ng }\end{array}$ & $\begin{array}{l}\text { Scatte } \\
\text { red }\end{array}$ & $\begin{array}{l}\text { Them } \\
\text { atic }\end{array}$ & \\
\hline \multirow{3}{*}{1} & $\begin{array}{l}\text { Coun } \\
\mathrm{t}\end{array}$ & 5 & 8 & 4 & 2 & 2 & 2 & 0 & 2 & 25 \\
\hline & $\begin{array}{l}\% \\
\text { withi } \\
\mathrm{n} \\
\text { Num } \\
\text { ber of } \\
\text { speec } \\
\mathrm{h}\end{array}$ & $20.0 \%$ & $32.0 \%$ & $16.0 \%$ & $8.0 \%$ & $8.0 \%$ & $8.0 \%$ & $0.0 \%$ & $8.0 \%$ & $\begin{array}{l}100 . \\
0 \%\end{array}$ \\
\hline & $\begin{array}{l}\% \text { of } \\
\text { Total }\end{array}$ & $5.3 \%$ & $8.4 \%$ & $4.2 \%$ & $2.1 \%$ & $2.1 \%$ & $2.1 \%$ & $0.0 \%$ & $2.1 \%$ & $\begin{array}{l}26.3 \\
\% \\
\end{array}$ \\
\hline \multirow{3}{*}{2} & $\begin{array}{l}\text { Coun } \\
\mathrm{t}\end{array}$ & 7 & 5 & 3 & 1 & 1 & 3 & 2 & 0 & 22 \\
\hline & $\begin{array}{l}\% \\
\text { withi } \\
n \\
\text { Num } \\
\text { ber of } \\
\text { speec } \\
\text { h }\end{array}$ & $31.8 \%$ & $22.7 \%$ & $13.6 \%$ & $4.5 \%$ & $4.5 \%$ & $13.6 \%$ & $9.1 \%$ & $0.0 \%$ & $\begin{array}{l}100 . \\
0 \%\end{array}$ \\
\hline & $\begin{array}{l}\% \text { of } \\
\text { Total }\end{array}$ & $7.4 \%$ & $5.3 \%$ & $3.2 \%$ & $1.1 \%$ & $1.1 \%$ & $3.2 \%$ & $2.1 \%$ & $0.0 \%$ & $\begin{array}{l}23.2 \\
\% \\
\end{array}$ \\
\hline 3 & $\begin{array}{l}\text { Coun } \\
t\end{array}$ & 6 & 2 & 4 & 0 & 1 & 4 & 1 & 0 & 18 \\
\hline
\end{tabular}




\begin{tabular}{|c|c|c|c|c|c|c|c|c|c|c|}
\hline \multicolumn{7}{|c|}{ 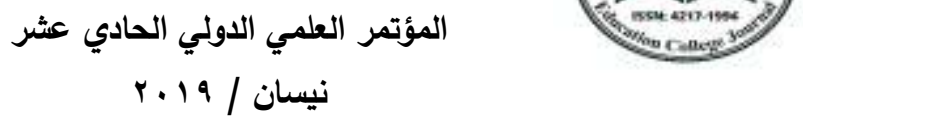 } & \multicolumn{4}{|c|}{ جامعة واسط } \\
\hline & $\begin{array}{l}\% \\
\text { withi } \\
\mathrm{n} \\
\text { Num } \\
\text { ber of } \\
\text { speec } \\
\mathrm{h}\end{array}$ & $33.3 \%$ & $11.1 \%$ & $22.2 \%$ & $0.0 \%$ & $5.6 \%$ & $22.2 \%$ & $5.6 \%$ & $0.0 \%$ & $\begin{array}{l}100 . \\
0 \%\end{array}$ \\
\hline & $\begin{array}{l}\% \text { of } \\
\text { Total }\end{array}$ & $6.3 \%$ & $2.1 \%$ & $4.2 \%$ & $0.0 \%$ & $1.1 \%$ & $4.2 \%$ & $1.1 \%$ & $0.0 \%$ & $\begin{array}{l}18.9 \\
\%\end{array}$ \\
\hline \multirow{3}{*}{4} & $\begin{array}{l}\text { Coun } \\
\mathrm{t}\end{array}$ & 4 & 3 & 2 & 2 & 0 & 1 & 2 & 2 & 16 \\
\hline & $\begin{array}{l}\% \\
\text { withi } \\
\mathrm{n} \\
\text { Num } \\
\text { ber of } \\
\text { speec } \\
\mathrm{h}\end{array}$ & $25.0 \%$ & $18.8 \%$ & $12.5 \%$ & $12.5 \%$ & $0.0 \%$ & $6.3 \%$ & $12.5 \%$ & $12.5 \%$ & $\begin{array}{l}100 . \\
0 \%\end{array}$ \\
\hline & $\begin{array}{l}\% \text { of } \\
\text { Total }\end{array}$ & $4.2 \%$ & $3.2 \%$ & $2.1 \%$ & $2.1 \%$ & $0.0 \%$ & $1.1 \%$ & $2.1 \%$ & $2.1 \%$ & $\begin{array}{l}16.8 \\
\%\end{array}$ \\
\hline \multirow{3}{*}{5} & $\begin{array}{l}\text { Coun } \\
t\end{array}$ & 5 & 4 & 1 & 0 & 2 & 0 & 2 & 0 & 14 \\
\hline & $\begin{array}{l}\% \\
\text { withi } \\
n \\
\text { Num } \\
\text { ber of } \\
\text { speec } \\
\text { h }\end{array}$ & $35.7 \%$ & $28.6 \%$ & $7.1 \%$ & $0.0 \%$ & $14.3 \%$ & $0.0 \%$ & $14.3 \%$ & $0.0 \%$ & $\begin{array}{l}100 . \\
0 \%\end{array}$ \\
\hline & $\begin{array}{l}\% \text { of } \\
\text { Total }\end{array}$ & $5.3 \%$ & $4.2 \%$ & $1.1 \%$ & $0.0 \%$ & $2.1 \%$ & $0.0 \%$ & $2.1 \%$ & $0.0 \%$ & $\begin{array}{l}14.7 \\
\%\end{array}$ \\
\hline \multirow[b]{2}{*}{ Total } & $\begin{array}{l}\text { Coun } \\
t\end{array}$ & 27 & 22 & 14 & 5 & 6 & 10 & 7 & 4 & 95 \\
\hline & $\begin{array}{l}\% \\
\text { withi } \\
n \\
\text { Num } \\
\text { ber of } \\
\text { speec } \\
\text { h }\end{array}$ & $28.4 \%$ & $23.2 \%$ & $14.7 \%$ & $5.3 \%$ & $6.3 \%$ & $10.5 \%$ & $7.4 \%$ & $4.2 \%$ & $\begin{array}{l}100 . \\
0 \%\end{array}$ \\
\hline
\end{tabular}




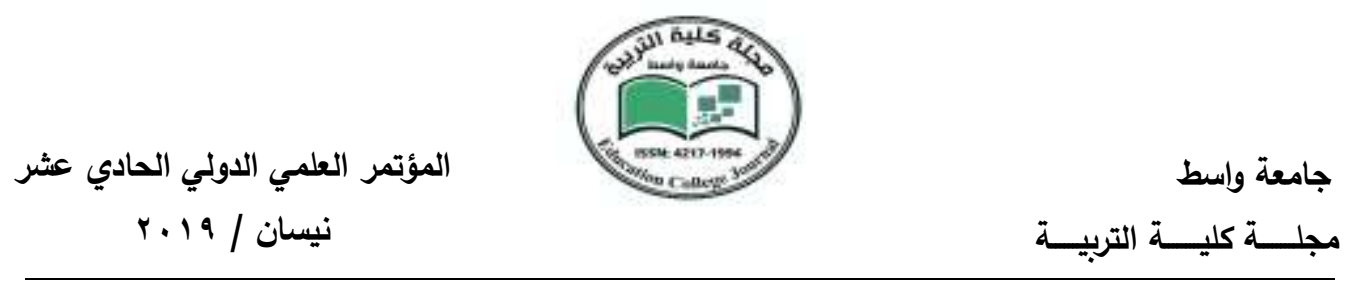

It is obvious from table (1) that only chain type of repetition is lacked in Trump's speeches while most other types are available but with unlike discrepancy .That is, thematic, rooted and framing sorts, for instance, are absent in speech ( 5 ) whereas scattered one is un existent in speech (1). Additionally, a Anaphora and Epiphora repetition are more frequent in use than others constituting (28.4\%) and (23.2 5\%) respectively. Thematic repetition, on the other hand, is the least in use in Trump's speech (4. $2 \%$ ). Such common use of the former two categories specifically can be related to the fact that repetition of a word, a phrase and even a sentence at the beginning (anaphora) enriches sound harmony of speech. Epiphora, on the other hand, adds to rhythmic blending of speech due to development of intonation and sound distinctiveness at final position of sentences. Further, both anaphora and epiphora aid in making a specific concept conveyed through a repeated word, phrase or sentence more distinctive and memorable to the audience. That distribution is further clarified in diagram (1)

Diagram (1)

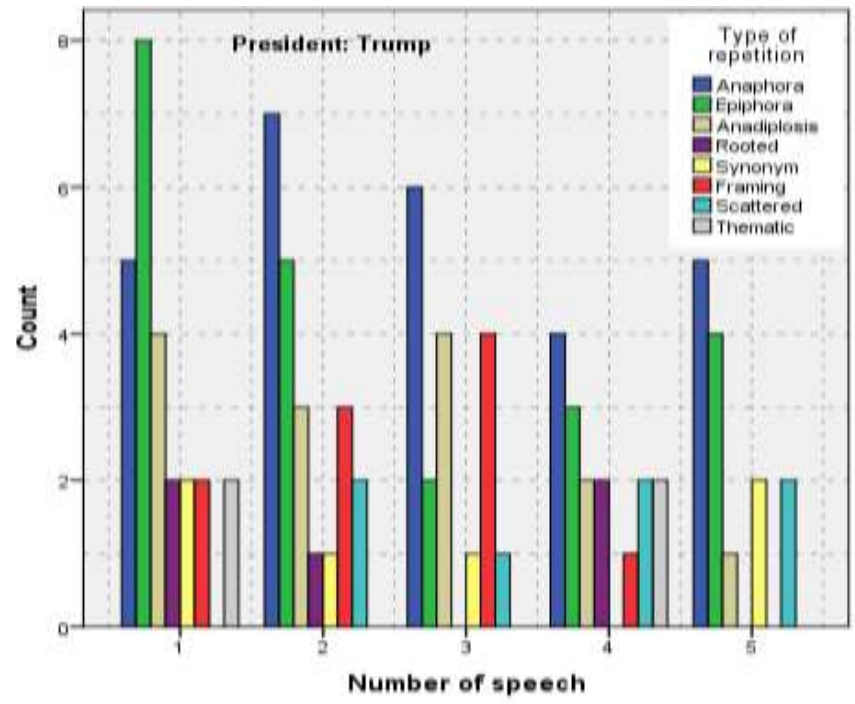



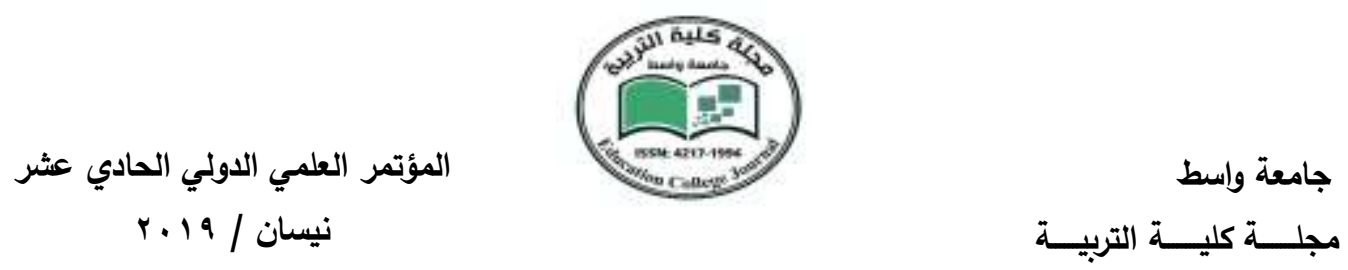

\section{6-2 Significance of Repetition in Political Discourse}

Depending on the theoretical background mentioned earlier regarding targets accomplished through repetition, the following motives are noticed in Trump's speeches :

\section{Persuasion}

One of the important semantic devices used in language to satisfy the task of persuasion is repetition in general . Huggard etal (2006:28-33) argue that such device reinforces the argument, manipulate the audience in a specific idea, and finally guides them to accept it .Trump , at the beginning of his first speech, for instance, apologizes to the audience and repeats the word " complicated" twice : " sorry to keep you waiting ,complicated, complicated business" . Actually, through that epiphora repetition, he wants to achieve two objectives .First, persuading the audience that his problematical business is the cause behind his being late. Second, showing people how he is the faithful man who cares for nothing except their profits as American citizens .

\section{Making a Point Memorable}

The fact that repetition commonly aids a lot in memorizing is witnessed in poetry as well as prose as it is noticed how the rhythmic unity conveyed through repetition helps in penetrating the listener's mind and then sticking there. Trump succeeds to make the idea that Iran lacks the nuclear weapon clear and memorable when he uses framing repetition and states "Iran cannot be allowed to have nuclear weapon, cannot be allowed . Remember that cannot be allowed to have a nuclear weapon".

\section{Cohesion}

Fairclough (1989: 130 ) mentions that cohesion refers to the recognized links between sentences and it encompasses vocabulary relations between sentences which can be achieved through repetition of words, or use of interrelated words. Fairclough's view then confirms the fact that Synonymous repetition which covers repetition of words that have similar meaning leads to cohesion .That is, Synonymous repetition succeeds to make a balance on lexical level and this leads to create cohesion in any discourse and political one is no exception .Trump , for instance, repeats the 

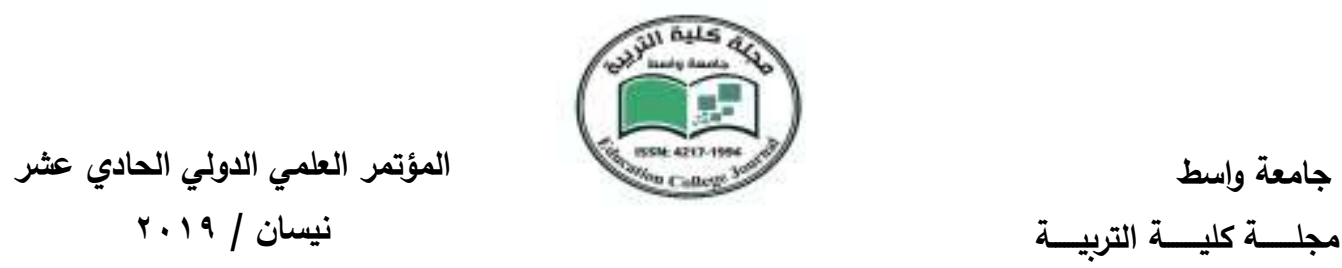

words "fairly" and "justly" in : " Our veterans have not been treated fairly or justly. Those are our great people and we must treat them fairly". Such repetition attains balance and then cohesion as lexical repetition is the first lexical cohesive device along with collocation in lexical category of cohesion . Hoey (1991:21 ) insists on the importance of lexical patterning and believes that much coherence as well as cohesion of a text is fulfilled by lexical ties of individual words with each other .

\section{Emphasis}

Regardless of the type of repetition used in political discourse , the emphasis function is grasped throughout the selected data . In using Anadiplosis repetition such as "I mean she. She fought very hard" or anaphora repetition “We will bring back our jobs. We will bring back our borders .We will bring back our wealth. We will bring back our dreams" , Trump emphasises the idea of Clinton' bravery or courage in the first example where as he confirms the vital responsibilities he is going to accomplish for Americans in the second one.

\section{Making a Point Memorable}

The fact that repetition commonly aids a lot in memorizing is witnessed in poetry as well as prose as it is noticed how the rhythmic unity conveyed through repetition helps in penetrating the listener's mind and then sticking there. Trump succeeds to make the idea that Iran lacks the nuclear weapon clear and memorable when he uses framing repetition and states "Iran cannot be allowed to have nuclear weapon, cannot be allowed . Remember that cannot be allowed to have a nuclear weapon".

\section{Elevating the Deeds of Significant Figures}

Trump intends deliberately to repeat the question " where is Robert ?" in "And my brother Robert ,my great friend. Where is Robert ? Where is Robert ?" to lift up the vital role played by Robert in reaching victory .In addition to that framing repetition, Trump repeats the name "Obama" here and there throughout the whole speech (scattered repetition) to high light the negative sides available in Obama's policy .In doing so, Trump indirectly 

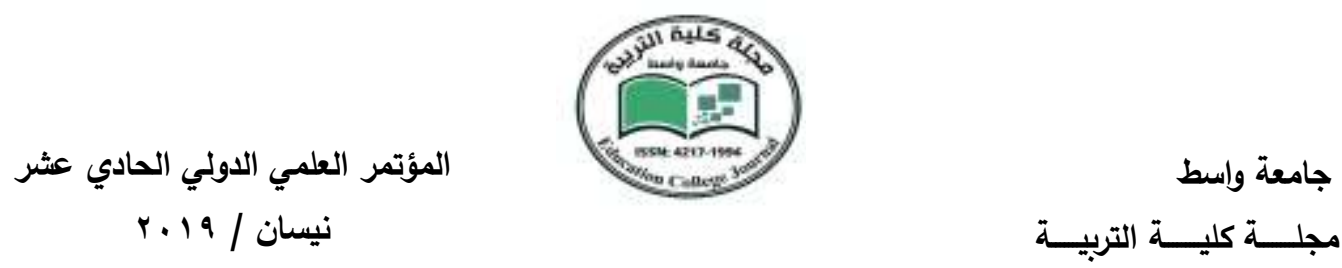

wants to show people that he is the most appropriate character in filling the gaps found in Obama's wrong policy.

\section{Illumination and Making Comprehension Easier}

Trump clarifies the idea of living in unity via repeating words carry similar meaning ( synonymous repetition ).He describes such life as being "good" and "pleasant" in : " The bible tells us how good and pleasant it is when God 's people live together in unity". Presenting such proof from the bible makes people not only comprehend the concept of unity easily but also persuade them in living a unified life. In their book Persuasive Language in Media Texts , Breuer and Napthine( 2005 :5-6) tackle the concept of persuasive techniques and state that " presenting an evidence is regarded as a reason for accepting a proposition or an idea ". Thus, Trump's proof from the bible helps in achieving the task of persuasion and illumination as well.

\section{Warning}

In addition to the motives mentioned above, the researchers notice that purpose of emphasis usually comes together with warning target which is expressed implicitly and inferred through context of the speech.

Repeating a word or a phrase accompanied with a rising intonation may apparently and successfully achieve the function of warning .Trump ,for instance, warns people from the violence of radical Islam and how they require to make a plan in order to stop its spread. Anadiplosis repetition of the phrase "The spread of radical Islam" in "First we need a long - term plan to halt the spread of radical Islam .The spread of radical Islam must be a major foreign policy goal of the United States " reflects the extent of Trump's fear from the spread of radical Islam and his attempt to let people share that feeling of horror through that repetition .

\section{Repetition and Ideology}

The analysis proves Trump' $\mathrm{s}$ use of repetition as a strategy to persuade his audience of his political ideology .In other words, he wants to pass his ideology which he needs in order to influence the audience of his political act. He uses a great deal of emotional expressions to attract his audiences' attention by giving promises of a better future .The emphatic repetition of 

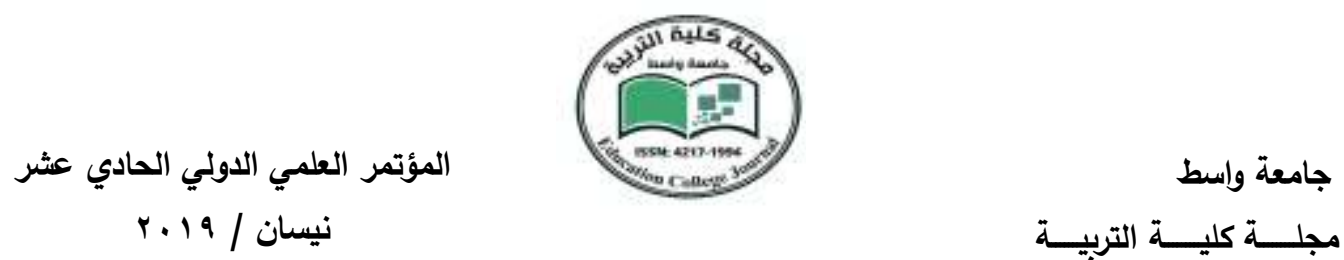

certain words like " our future, dream , our country, rebuild" are used to evoke the people's impression that the best situation that will happen in the future, for example,

1. "We 're going to dream of things for our country".

2. "No dream is too big".

3. "We "re going to rebuild our infrastructure".

4. "We are going to fix our inner cities and rebuild our highways".

5. "And we will put millions of our people to work as we rebuild it".

6. "We , the citizens of America ,...We will determine the course of America".

7. "We will face the challenge. We will confront the hardship .But we will get the job done".

Trump is a representative of Republican political group which has a social ideology expressed through a discourse. When ideology is hidden, as Van Dijk(2006) mentions, it has a tremendous influence. A hidden ideology exists in Trump's use of emotive words to influence his audience towards his particular ideology. All what he said concerns all the nation and for its interests. The phrase repetition of "our people" is to elevate people's emotions and to show his care of them.

Trump uses an informal style to carry the feelings of solidarity and friendship with the people in an attempt to break the boundaries and to appear more close to them. This is a manipulative strategy used to gain the their sympathy and support in ruling the country. Jerit etal.(2000:8) points out that " politicians intend to activate emotions in the process of shaping citizens' beliefs about future outcomes".

The repetition of "we "re" is to emphasize the unity matter which helps in solidifying the victory situation against the Democratic opponent. Such a word use is the most emotional in a society. It used by politicians to maintain the ideology of staying in power. Trump is playing with the people's patriotic emotions to persuade them of a better future and that he will do the best for the country .The emotive language is also used to show that his speech is a sincere one coming from the heart. 

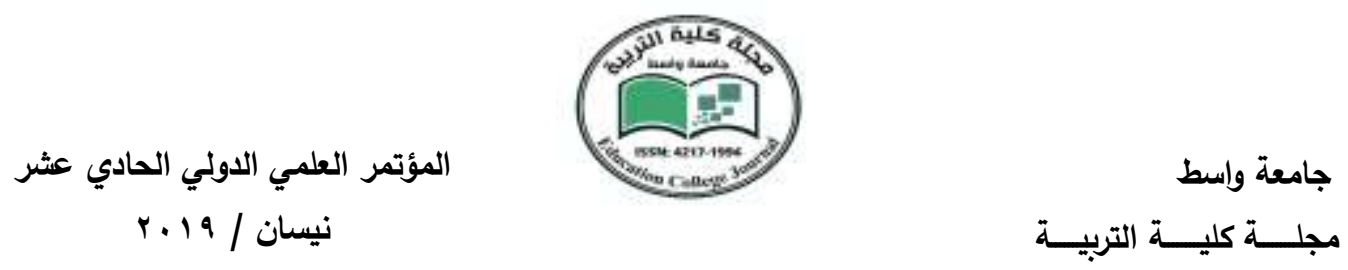

Besides, Trumps uses another strategy which is the unification .It is used to convince the Americans that he comes to unify them when he pledged to be the president of unity. As a politician, Trump uses pronouns to " reveal ideological bias ; to encourage solidarity ; to designate and identify those who are supporters" ( Wlison,1990:76).This strategy has a tremendous emotional impact on the people to stay on his side. Trump through pronominal repetition establishes a sense of unity, and shared identity and memebership. See the examples above.

Another strategy is noticed in Trump's repetition which is the promising. It is used as a prominent feature in his speech. This employment is probably manipulated to win the audiences' hearts as he will make the best for them. A promise to help the country use its wealth and recourses, to give more jobs , to bring back borders, wealth, and dreams. With Trump, American people are strong, competitive and that can restore their glory. See the example below:

8. "We will bring back our jobs. We will bring back our borders. We will bring back our wealth. And we will bring back our dreams".

The ideological strategies carry a message to convince the people of his beliefs, ideas and visions.Trump wants the people to support him , follow his government and its administration, so they can gain success and achieve their dreams.

Furthermore, Trump uses the system of polarization of "us" vs "them. These are mitigating methods to manipulate peoples' cognition by showing his selfpositive representation of his image as a well-deserved president who listens to the people's needs. The negative attitudes of them changes according to the context. Below is the categories of ideological representation in Trump's speech. 

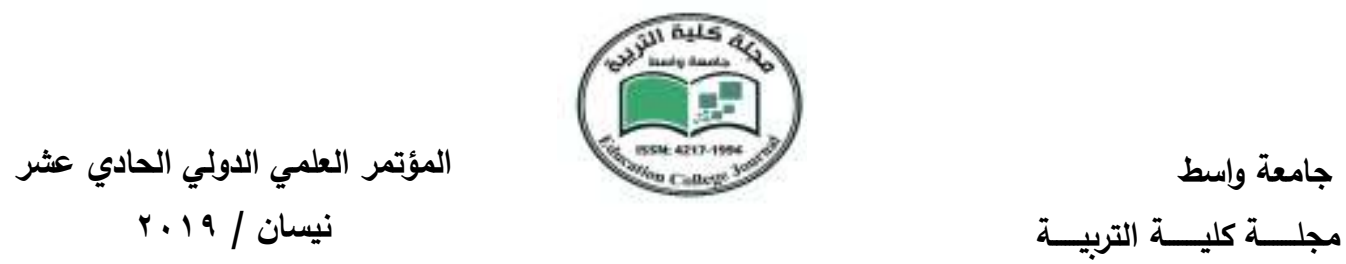

\begin{tabular}{|l|l|l|}
\hline classes & Representation & Referents \\
\hline We , us & American, our country & We , us , our \\
\hline Opponents & $\begin{array}{l}\text { The Democratic , Obama , Clinton } \\
\text {,previous government }\end{array}$ & they, Them , he \\
\hline Foreigners & Iran , Radical Islam, terrorists & They, them \\
\hline
\end{tabular}

1.Sometimes the use of 'them' refers to the previous government and his opponents as bad representatives of America when they distanced themselves from the American people. He is blaming "them" in a selfdefense manner. The repetition of the word "weaken" occurs many times in Trump's speech . Consider the following example.

9-“President Obama weakened our military by weakening our economy". 10."If president Obama's goal had been to weaken America, he could not have done a better job".

The root repetition of the word "weaken" is mainly used by Trump to show the willingness and intention of his new administration to fulfill the objectives of its political program. He presents contrasts between the negative past of America under the Democratic administration and a positive outlook in the future state of affairs under his administration.

2- Another use of "other" is represented by the lexical repetition of "radical Islam”, for example :

11-We 're in a war against radical Islam.

12. Containing the spread of radical Islam must be a major foreign policy of the United States.

13. All of which are at risk from radical Islamic violence.

14. The struggle against radical Islam also takes place in our homeland.

The occurrence of "war, threat, violence, terrorism, etc." with "radical Islam" seems to be ideologically motivated. It is clear that the repetition of "radical Islam" with "war" is to project a negative image of Muslims as war-loving 

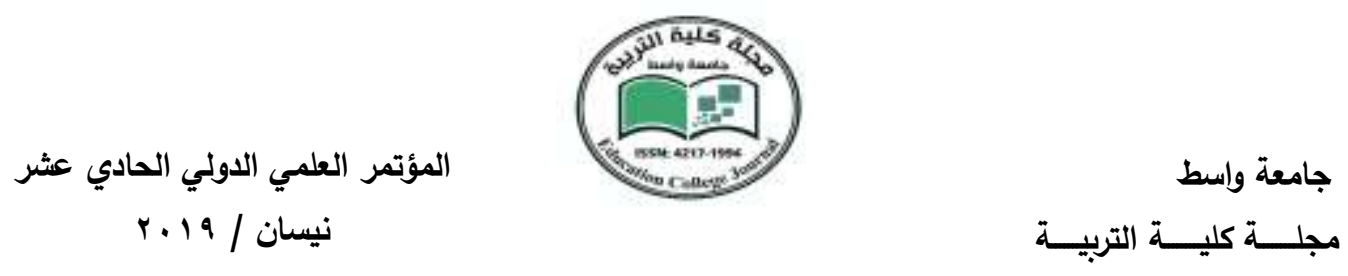

who are only found of aggression .By this, Trump is preparing the people for a real conflict in the near future. This is a binary opposition created by the employment of Ideological Square in which America and its allies (in groupwe) are given a superior position capable of defeating "radical Islam" (outgroup-they) via waging a war against them. This strategy puts "radical Islam" in a negative inferior image through which the audiences are almost persuaded that "radical Islam" deserves punishment in a form of war in a way to legitimize and justify this movement against "them" .

\section{Conclusion}

Trump's discourse witnesses the presence of most types of repetition but with discrepancy in frequency and use. Trump practices anaphora and epiphora repetition.Trump grasps well how repetition at initial or final position of a sentence intensifies the rhythmic blend of speech which in its turn make a specific notion more striking. Trump exercises repetition for accomplishing clarification, eminence, persuading, making a point unforgettable ,and creating unity. Further, it is noticed that the use of warning combined with emphasis is frequent and it is recognized implicitly rather than explicitly via speech context .

Trump uses a great deal of emotional expressions to attract his audiences' attention to his ideology to convince the people of his beliefs, ideas and visions. Another strategy is the unification that he comes to unify them when he pledged to be the president of unity. The system of polarization of " $u$ " " vs "them" is used to manipulate peoples' cognition by showing his self-positive representation of his image while the negative attitudes of them changes according to the context such as " The Democratic , Obama , Clinton ,previous government, Iran, or Radical Muslims". 

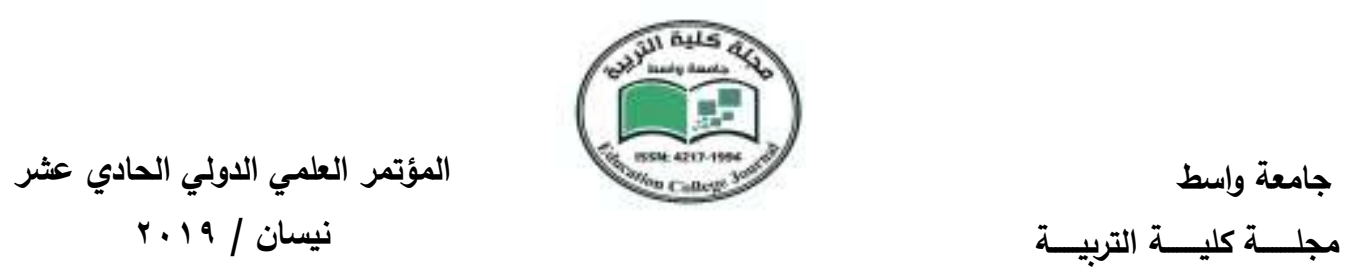

\section{References}

Breuer, I. and Napthine,M.(2008) .Persuasive language in media texts.Hyde park press.

Cuddon, J. A. (1998). Dictionary of Literary Terms and Literary Theory._London: Penguin Books.

Fairclough , N .(1989) .Language and Power .New York. Longman Group UK Limited . ( 1992) Discourse and Social Change .Cambridge : Polity Press.

Hall,S.(1996) “The Problem of Ideology:Marxism without Guarantees”, in D.Morley and K.H. Chen (eds.), Stuart Hall: Critical Dilalogues in Critical Studies.London: Routledg. PP.25-46.

Hodge, R., and Kress, G.(1993) Language as Ideology ( $2^{\text {nd }}$ ed.).London:Routledge.

Hoey, S. 1991 . Textual Cohesion . London : Macmillan publisher, Ltd. Australia.

Huggard, R., Leonie K. \&, Iris B. 2006. Insight Outcomes English year 12. Oxford : Oxford university press. Mentone, Victoria: Insight. Publication.

Kemertelidze,N. and Manjavidze,T.(2013). "Stylistic Repetition , ITS Peculiarities and Types in Modern English”. European Scientific Journa.1 July 2013 /SPECIAL/ edition

Power, Mary R. (1998). Working Through Communication. Cambridge : Cambridge University press .

Sandell, Rolf (1977). Linguistic Style and Persuasion. London: Academic Press.

Thompson, J.B (1990) Ideology and Modern Culture. Cambridge: Polity Press.

van Dijk,T ( 1995) “Discourse Semantics and Ideology”. Discourse and Society.6:2,243289.

.. (1998) Ideology: A Multidisciplinary Approach.London: SAGE Publication Ltd.

...(2001b) "Discourse , Ideology and Context: A sociocognitive Approach".Folia Linguistica, xxx/1-2,11-40.

Yemenici, Alev (2002). “. Categories and Functions of Repetition in Turkish Oral Narratives”. Boğaziçi University Journal of Education.Vol.19, No.1, pp.13-35. 
تشهد المناقثات الصعبة بما في ذلك السياسية وجود العديد من طرق نقل الآر اء ذات الصلة ولكنها

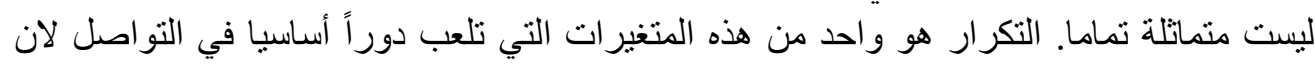

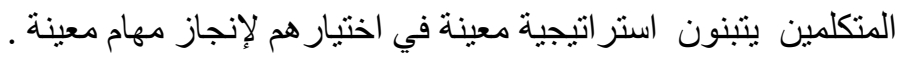

تبحث الدر اسة الحالية ظاهرة التكرار،و انو اعها ، و الفئات، و الدو افع الكامنة ور اء ظهورهاو وظيفة

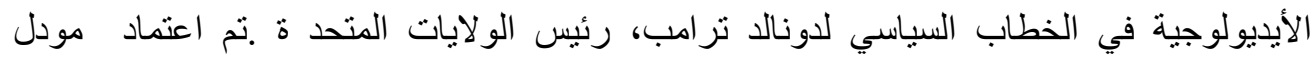

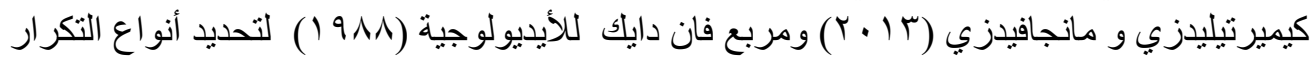

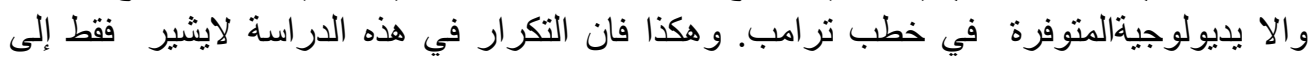

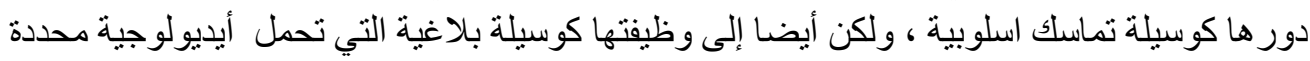

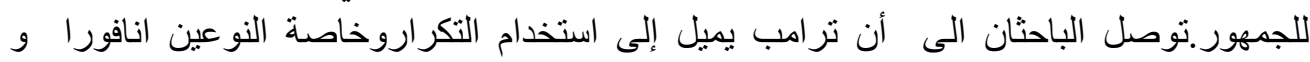

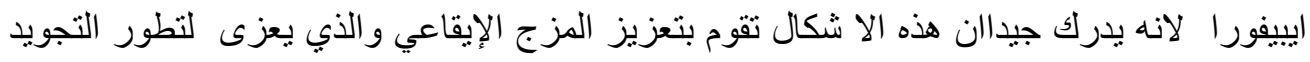

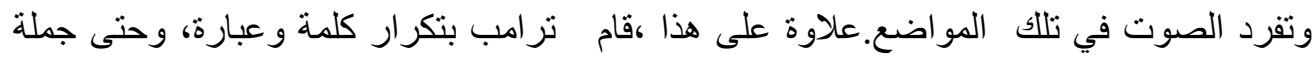

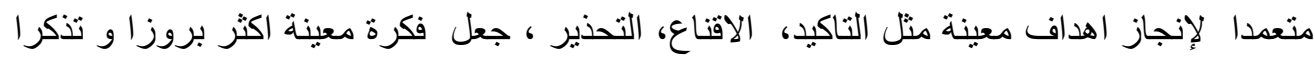

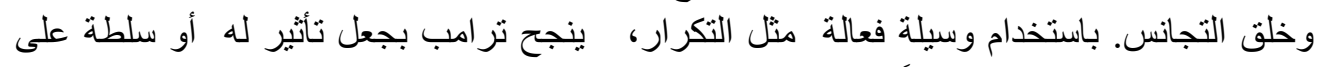

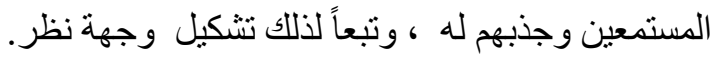

